\title{
PENGARUH PENKES MENGGUNAKAN METODE CERAMAH DAN LEAFLET TERHADAP TINGKAT KECEMASAN PRIMIGRAVIDA
}

\author{
Yuli Suryanti \\ Dosen Program Studi D III Kebidanan STIKES Mitra Adiguna Palembang \\ Komplek Kenten Permai Blok J 9-12 Bukit Sangkal Palembang 30114 \\ Email : yulisuryanti21@gmail.com
}

\begin{abstract}
Abstrak
Pendidikan kesehatan merupakan cara penyampaian informasi kesehatan yang mudah diterima oleh ibu hamil dengan berbagai media yang digunakan. Masalah emosional yang terjadi pada kehamilan trimester III adalah perasaan cemas. Penelitian ini bertujuan untuk menganalisa pengaruh pendidikan kesehatan menggunakan metode cemarah dan leaflet terhadap tingkat kecemasan ibu hamil trimester III. Penelitian Quasi Experiment dengan pre-test dan post-test group sebanyak 48 responden dengan teknik Purposive Sampling. Instrumen yang digunakan untuk mengukur skala kecemasan Taylor Manifest Anxiety Scale (TMAS). Analisis data menggunakan Paired T test dan Independen T test. Hasil penelitian di dapatkan ada perbedaan tingkat kecemasan ibu hamil trimester III sesudah diberikan pendidikan kesehatan dengan menggunakan metode ceramah dan leaflet dengan nilai $p=0,000$. Pendidikan kesehatan yang diberikan pada ibu hamil saat melakukan pelayanan antenatal terbukti mampu meningkatkan pengetahuan ibu hamil terhadap kehamilannya. Leaflet sangat efektif untuk menyampaikan pesan singkat dan padat media ini juga mudah dibawa dan disebarluaskan karena ukurannya lebih ringkas dan jumlah yang dibawa lebih banyak dari pada poster.
\end{abstract}

Kata kunci : Cemas, Ibu Hamil, Taylor Manifest Anxiety Scale

\begin{abstract}
Health education is a way of conveying health information that is easily accepted by pregnant women with various media used. The emotional problem that occurs in the III trimester of pregnancy is the feeling of anxiety. This study aims to analyze the influence of health education using cemarah and leaflet methods on the anxiety levels of pregnant women in the III trimester. Quasi Experiment research with pre-test and posttest group of 48 respondents with Purposive Sampling technique. Instruments used to measure the Taylor Manifest Anxiety Scale (TMAS) anxiety scale. Data analysis using Paired T test and Independent T test. The results of the study found there was a difference in the anxiety level of pregnant women trimester III after being given health education using lecture methods and leaflets with a value of $p=0.000$. Health education provided to pregnant women when performing antenatal services is proven to improve the knowledge of pregnant women to their pregnancy. Leaflets are very effective for conveying short and solid messages this medium is also easy to carry and disseminate because of its more compact size and the number carried more than on posters.
\end{abstract}

Keywords : Worried, Expectant Mother, Taylor Manifest Anxiety Scale

Jurnal Kesehatan dan Pembangunan, Vol. 11, No. 22, Juli 2021 


\section{PENDAHULUAN}

Pendidikan kesehatan merupakan serangkaian upaya untuk mempengaruhi orang lain baik individu, keluarga, kelompok ataupun masyarakat untuk memberikan informasi pada pasien. Dalam hal ini pendidikan kesehatan digunakan untuk mengurangi tingkat kecemasan pada ibu hamil trimister III. Bidan berperan penting dalam keterampilan dan pengetahuan untuk menyampaikan informasi mengenai kesehatan melalui pendidikan kesehatan saat memberikan pelayanan khususnya antenatal care. (Pramudianti, 2017)

Metode yang digunakan dalam memberikan pendidikan kesehatan bisa menggunakan metode ceramah dan metode leaflet. Metode ceramah merupakan metode yang digunakan dalam penyampaian pesan secara lisan atau berbicara secara lansung yang disertai dengan tanya jawab pada sasaran. Sedangkan leaflet merupakan salah satu jenis media cetak yang isinya berupa informasi kesehatan melalui lembar yang dilipat. (Induniasih, 2018)

Metode ceramah memiliki kekurangan yaitu bersifat pasif, kurang aktif untuk mencari dan mengola informasi hanya sedikit penyuluh yang dapat menjadi pembicara yang baik, tidak semua sasaran mempunyai daya tangkap yang sama, sering menimbulkan verbalisme pada sasaran, sasaran dapat mengucapkan kata tepi tidak mengetahui artinya, sulit mendapat feedback dari sasaran, sering menimbulkan salah paham, karena sasaran salah mengartikannya. Mendengarkan ceramah dalam waktu yang cukup lama dapat membosankan, sehingga mengganggu kosentrasi berpikir dari sasaran.

Alternatif penyampaian materi dapat dilakukan dengan memberikan leaflet pada peserta. Leaflet adalah media berbentuk selembar kertas yang diberi gambar dan tulisan (biasanya lebih banyak tulisan) pada kedua sisi kertas serata dilipat sehingga berukuran kecil dan praktis dibawa, biasanya ukurannya A4 dilipat tiga. Media ini berisikan suatu gagasan secara langsung ke pokok permasalahannya dan memaparkan cara melakukan tindakan secara pendek dan lugas. Leaflet sangat efektif untuk menyampaikan pesan singkat dan padat, media ini juga mudah dibawa dan disebarluaskan karena ukurannya lebih ringkas dan jumlah yang dibawa lebih banyak dari pada poster.

Keuntungan leaflet yaitu dapat membantu petugas memberikan pelajaran, daya tangkap penglihatan lebih besar, sebagai alat penghubung yang dapat menyampaikan berita-berita dan penjelasan-penjelasan kepada masyarakat dalam jumlah yang besar, kesempatan untuk belajar kembali akan lebih banyak, mudah dibawa dan disebarluaskan, proses pembuatan relatif cepat dan murah, efektif untuk pesan yang singkat dan padat, bisa dibuat sederhana. Kekurangan leaflet adalah butuh illustrator untuk memberi gambaran, penguasaan computer (lay out), memerlukan keterampilan baca tulisan, mudah hilang dan rusak, pesan yang disampaikan terbatas.

Masalah yang sering terjadi pada kehamilan trimester III antara lain cemas, yaitu kondisi emosional yang tidak menyenangkan yang ditandai oleh perasaanperasaan subjektif seperti ketegangan, ketakutan, kekhawatiran dan juga ditandai dengan aktifnya sistem saraf pusat. Hal ini terjadi karena kecemasan memicu produksi Cortiotrophin Releasing Hormone (CRH) yaitu hormon yang membuat detak jantung ibu menjadi cepat sehingga ibu dapat melahirkan bayi prematur atau lebih kecil dari bayi normal lainnya bahkan mengalami keguguran. (Arief, 2010)

Penelitian lain yang berkaitan dengan kecemasan di klinik Hj. Hadijah dengan judul kecemasan ibu primigravida dalam menghadapi persalinan setelah menonton video proses persalinan normal didapatkan hasil bahwa $46 \%$ ibu mengalami kecemasan ringan, 50\% mengalami kecemasan sedang, dan $4 \%$ mengalami kecemasan berat. Hasil penelitian tersebut menunjukkan bahwa 
kecemasan bisa berkurang dengan memberikan pendidikan kesehatan antara lain dengan memutarkan video. Kecemasan yang dialami oleh ibu hamil tersebut disebabkan karena persepsi ibu yang kurang mengenai proses persalinan dipersepsikan sebagai proses yang menakutkan dan menimbulkan rasa sakit yang luar biasa. Ibu hamil merasakan kecemasan yang hebat menjelang bayinya.(Ilmiasih, 2014)

$\begin{array}{cccc}\text { Ada } & \text { beberapa } & \text { faktor } & \text { yang } \\ \text { menyebabkan } & \text { kecemasan } & \text { antara } & \text { lain } \\ \text { interpersonal } & \text { (kecemasan } & \text { timbul } & \text { dari }\end{array}$
perasaan takut terhadap tidak adanya penerimaan dan penolakan interpersonal), behaviour (prilaku), biologi (kesehatan), dan keluarga. Keluarga merupakan lingkungan yang membentuk kepribadian seseorang dari kecil hingga dewasa, dalam keluarga yang paling sering muncul adalah dukungan keluarga. Dukungan keluarga yang dimiliki calon ibu akan menunjukan perasaan tenang, sikap positif, terhadap diri sendiri dan kehamilannya, atau sebaliknya. Dengan dukungan keluarga diharapkan wanita hamil dapat mempertahankan kondisi kesehatan psikologinya dan lebih mudah menerima perubahan fisik serta mengontrol emosi dan mempersiapkan untuk proses persalinan.(Dagu, 2010)

Persalinan adalah suatu proses yang dimulai dengan adanya kontraksi uterus yang menyebabkan terjadinya dilatasi progresif dari serviks, kelahiran bayi, dan kelahiran plasenta, proses tersebut merupakan proses alamiah. Proses persalinan dipengaruhi jalan lahir (passage), faktor janin (passanger), faktor kekuatan (power), faktor psikis juga sangat menentukan keberhasilan persalinan. Rasa takut dan khawatir dapat menimbulkan rasa ketegangan atau kepanikan yang menyebabkan otot-otot menjadi kaku dan akhirnya menyebabkan rasa sakit. Ketakutan atau kecemasan ibu dalam menghadapi persalinan terutama ibu hamil primigravida berkaitan dengan emosi ibu yang berpengaruh pada proses persalinan.(Risqi, 2015)
Perasaan takut yang menghantui ibu hamil saat akan menjelang persalinan seakan ada sesuatu yang buruk dan tidak nyaman mengancam dirinya, seringkali perasaan cemas menyertai kehamilan akan mencapai puncaknya. pada saat persalinan. Seorang ibu mungkin merasakan takut akan rasa sakit dan bahaya fisik yang akan timbul pada waktu persalinan, karena pada saat persalinan ibu membutuhkan mental yang kuat secara fisik maupun psikologinya, kerja keras serta perjuangan untuk keselamatan ibu dan bayinya. Dampak dari kecemasan yang dialami pada ibu adalah tidak nafsu makan, tidak bisa tidur, sering melamun sendiri, sulit diajak untuk komunikasi. (Rahmat \& Siswosudarmo, 2014)

Berdasarkan hasil wawancara ibu hamil yang melakukan pemeriksaan kehamilan pada bulan November 2018 di BPM Y Kota Palembang didapatkan 6 orang ibu primigravida, hasil wawancara yaitu 4 orang mengalami ketakutan dalam menghadapi persalinan sehingga membuat ibu tidak nafsu makan, tidak bisa tidur dan sering melamun sendiri, terutama keadaan bayinya normal atau tidak dan ketakutan bila nanti persalinannya mengalami sakit, sedangkan 2 ibu tidak mengalami ketakutan dalam menghadapi persalinan karena kehamilannya sangat diinginkan dan sudah dipersiapkan selama dua tahun setelah menikah. Ibu hamil primigravida bisa mengalami kecemasan menjelang persalinan karena kurang pengetahuan, ibu hamil belum pernah mengalami persalinan, takut akan proses pembedahan, faktor biaya yang mahal, nyeri, perubahan keadaan fisik, usia serta faktor lingkungan dan pendidikan. Bidan selalu memberikan pendidikan saat ibu hamil melakukan pemeriksan kehamilan. Sehingga penelitian ini bertujuan untuk menganalisa perbedaan tingkat kecemasan ibu hamil primigravida trimester III sesudah diberikan pendidikan kesehatan dengan menggunakan metode ceramah dan leaflet di BPM Y Kota Palembang. 


\section{METODE PENELITIAN}

Penelitian ini merupakan jenis penelitian kuantitatif berupa eksperimental semu (quasi experiment) dengan desain pretest dan post-test grup. Peneliti melakukan penggalian terhadap tingkat kecemasan, grup 1 diberikan pendidikan kesehatan dengan metode ceramah dan grup II menggunakan metode leaflet. Penelitian ini dilakukan di BPM Y Kota Palembang. Populasi penelitian ini yaitu semua ibu hamil primigravida trimester III yang melakukan pemeriksaan kehamilan tanggal 1 Desember 2020 - 4 Januari 2021 berjumlah 48 orang. Teknik sampling menggunakan pendekatan Purposive Sampling. Kriteria eksklusi sampel adalah ibu yang sudah melahirkan sebanyak 10 orang, pindah rumah 3 orang, 1 orang tidak berangkat dan 4 orang tidak melengkapi pengisian kuesioner sehingga jumlah sampel sebanyak 30 orang. Instrumen yang digunakan untuk mengukur skala kecemasan adalah kuesioner berdasarkan Taylor Manifest Anxiety Scale (TMAS) yang terdiri dari 24 butir pertanyaan (10 butir pertanyaan sikap dan 14 butir lainnya berupa gejala somatic). Analisa data dimulai dengan melakukan ujinormalitas data dengan parameter Kolmogorov-Smirnov dengan nilai kemaknaan $p>0,05$. Analisa univariat disajikan dalam bentuk tendensi sentral berupa nilai maksimum, minimum, mean, median, modus, dan standar deviasi serta distribusi frekuensi dan prosentase dari masing-masing variabel. Sebelum melakukan uji perbedaan peneliti melakukan uji normalitas data menggunakan Shapiro Wilk. Pada data berpasangan hasil uji normalitas yaitu normal sehingga dilakukan uji beda dua sampel dengan paired $\mathrm{T}$ test, dan data tidak berpasangan hasil uji normalitas juga normal sehingga dilakukan uji independen $\mathrm{T}$ test.

\section{HASIL PENELITIAN}

Tabel 1. Tingkat kecemasan ibu hamil primigravida trimester III dalam menghadapi persalinan sebelum diberikan pendidikan kesehatan dengan menggunakan metode ceramah dan leaflet di BPM Y Kota Palembang ditunjukkan dalam tabel berikut :

\begin{tabular}{ccccccc}
\hline Variabel & Klp & N & Min & Max & Mean & SD \\
\hline $\begin{array}{c}\text { Tingkat } \\
\text { kecemasan }\end{array}$ & $\begin{array}{c}\text { Sebelum } \\
\text { (ceramah) }\end{array}$ & 15 & 6 & 11 & 9,13 & 1,552 \\
\hline & $\begin{array}{c}\text { Sebelum } \\
\text { (leaflet) }\end{array}$ & 15 & 7 & 20 & 11,80 & 3,629 \\
\hline
\end{tabular}

Berdasarkan tabel 1 hasil analisis univariat sebelum diberi leaflet rata-rata tingkat kecemasan ibu hamil primigravida trimester III dalam menghadapi persalinan di BPM Y Kota Palembang lebih tinggi dari pada kelompok sebelum diberikan ceramah, dimana kelompok leaflet rata-rata 11,80 dengan standar deviasi 3,629 dan kelompok ceramah rata-rata 9,13 dengan standar deviasi 1,552 .

Berdasarkan analisa penelitian umur ibu hamil kebanyakan masih muda sekitar umur 18-20 tahun. Umur ibu hamil dapat mempengaruhi proses kematangan berfikir seseorang, selain itu tingkat pendidikan ibu sebagian besar adalah SMA tetapi masih ada ibu yang berpendidikan SMP, hal ini dapat mempengaruhi pengetahuan dan informasi ibu tentang persalinan. Informasi yang didapatkan ibu hamil mengenai persalinan masih minim biasanya informasi tersebut hanya didapatkan dari orang awam yang pengetahuannya masih kurang mengenai proses persalinan.(Kundre \& Silolonga, 2014)

Dukungan sosial seperti informasi dan emotional support dari bidan berupa pemberian pendidikan kesehatan tentang persalinan, dukungan dan interaksi keluarga juga dapat membantu mengatasi tingkat kecemasan dalam menghadapi persalinan. Keluarga dihubungkan oleh ikatan yang sangat kuat saat menjalani kejadian yang mengkhawatirkan, segala hal yang mempengaruhi semua anggota keluarga maka akan mempengaruhi kecemasan yang dialami individu, peran keluarga dalam menimbulkan 
kecemasan meliputi, adanya konflik, dukungan keluarga yang diberikan ketika menghadapi peristiwa penting dalam kehidupan. (Pevi Primasnia, Wagiyo, 2013)

Tingkat kecemasan pada ibu hamil trimester III pada kelompok ceramah dan leaflet berbeda yaitu rata-rata lebih tinggi pada kelompok sebelum ceramah dibandingkan sebelum leaflet. Leaflet adalah salah satu metode yang cukup efektif dalam melakukan pendidikan kesehatan, dengan cara tersebut peneliti dapat menerangkan suatu pengertian atau pesan kepada responden, ceramah diberikan secara lisan disertai dengan tanya jawab kepada ibu hamil trimester III. Leaflet adalah bentuk penyampaian informasi atau pesan-pesan kesehatan melalui lembaran yang dilipat, informasi dapat dalam bentuk kalimat maupun gambar, atau kombinasi.

Tabel 2. Tingkat Kecemasan Ibu Hamil Primigravida Trimester III dalam Menghadapi Persalinan Sesudah diberikan Pendidikan Kesehatan dengan Metode Ceramah dan Metode Leaflet di BPM Y Kota Palembang

\begin{tabular}{ccccccc}
\hline Variabel & Klp & N & Min & Max & Mean & SD \\
\hline $\begin{array}{c}\text { Tingkat } \\
\text { kecemasan }\end{array}$ & $\begin{array}{l}\text { Sesudah } \\
\text { (cerama) }\end{array}$ & 15 & 4 & 9 & 6,13 & 1,642 \\
& $\begin{array}{l}\text { Sesudah } \\
\text { (leaflet) }\end{array}$ & 15 & 6 & 15 & 9,20 & 2,426 \\
\hline
\end{tabular}

Berdasarkan tabel 2 hasil analisis univariat sesudah perlakuan leaflet rata-rata tingkat kecemasan ibu hamil primigravida trimester III dalam menghadapi persalinan di BPM Y Kota Palembang lebih tinggi dari pada kelompok ceramah karena rata-rata tingkat kecemasan kelompok leaflet sudah tinggi dibandingkan kelompok ceramah. Tingkat kecemasan kelompok leaflet rata-rata 9,20 dengan standar deviasi 2,426 dan kelompok ceramahrata-rata 6,13 dengan standar deviasi 1,642.

Berdasarkan piramida pembelajaran Miller secara garis besar model pembelajaran itu terbagi menjadi dua yaitu aktif dan pasif. Model pembelajaran pasif, rata-rata itulah model yang masih digunakan secara umum dalam model belajar saat ini. Membaca memberikan penguasaan materi $10 \%$, mendengarkan $20 \%$ dan melihatnya secara langsung memberikan kontribusi sebesar $30 \%$. Melihat dan mendengar $50 \%$. Sedangkan model pembelajaran aktif dimana ketika kita "mengatakan" atau mengajarkan orang" atau berdiskusi maka itu bisa memberikan $70 \%$ pemahaman terhadap materi yang dikuasai, serta jika kita aktif melakukan/mengaplikasikan ilmu maka hal tersebut berkontribusi $90 \%$ terhadap pemahaman taerhadap materi yang diberikan.

Pembelajaran piramida diatas dapat disimpulkan bahwa belajar yang kurang efektif adalah mengandalkan hanya dengan membaca dan mendengarkan saja, tanpa ditindaklanjuti oleh perbuatan apapun. Belajar yang lebih efektif adalah dengan belajar aktif, mendiskusikan hasil materi yang didapat (entah itu membaca atau mendengarkan), mengajarkannya kembali, mempresentasikan, dan juga mengaplikasikannya dalam kehidupan nyata.

Pendidikan kesehatan menggunakan metode ceramah memberikan penguasaan materi sebesar $20 \%$ karena ibu hamil hanya mendengarkan, berdasarkan piramida miller ceramah merupakan salah satu model pembelajaran pasif. Apabila disertai pembelajaran secara aktif memiliki nilai $70 \%$ yaitu dengan cara menerangkan suatu pengertian atau pesan secara lisan disertai dengan tanya jawab kepada sasaran pendidikan menggunakan alat bantu pendidikan seperti slide dalam waktu 30 menit. Pelaksanaan ceramah dimulai dengan memperkenalkan diri, mengemukakan maksud dan tujuan serta harapan yang ingin dicapai, penjelasan secara sistematis isi dari ceramah yang akan diberikan, suara cukup keras dan turun naik sehingga tidak membosankan, diselingi humor segar, usahakan suasana ceramah tersebut menyenangkan, setiap tiga menit berikan waktu untuk mengajukan pertanyaan bagi 
sasaran, menggunakan bahasa yang mudah dimengerti, menjawab pertanyaan dengan menyakinkan, usahakan setiap pertanyaan dijadikan bahan diskusi, ketika akan mengakhiri ceramah buatlah tinjauan kembali, dan setelah selesai ceramah beramah tamahlah dahulu dengan para pendengar. Keuntungan dari ceramah adalah metode ini murah dan mudah dilakukan, Pemakaian waktu dapat dikendalikan oleh penyuluh, bersifat luwes, penyuluh dapat menjelaskan dengan menonjolkan bagian yang penting dan tidak terlalu melibatkan alat peraga.

Leaflet memberikan penguasaan materi sebesar $30 \%$ yaitu dari membaca $10 \%$ dan mendengarkan $20 \%$ tetapi apabila dibuat mode menjadi 1 pembelajaran secara aktif dapat memberikan penguasaan materi sebesar 90\%. Leaflet merupakan salah satu jenis media cetak yang berisi informasi atau pesanpesan kesehatan melalui lembaran yang dilipat, informasi dapat dalam bentuk kalimat maupun gambar, atau kombinasi. Pelaksanaan leaflet dimulai dengan memperkenalkan diri, mengemukakan maksud dan tujuan serta harapan yang ingin dicapai menjelaskan isi dari leaflet, usahakan suasana leaflet tersebut menyenangkan, setiap tiga menit berikan waktu untuk mengajukan pertanyaan bagi sasaran, menggunakan bahasa yang mudah dimengerti, menjawab pertanyaan dengan menyakinkan, usahakan setiap pertanyaan dijadikan bahan diskusi, ketika akan mengakhiri dalam menjelaskan leaflet buatlah tinjauan kembali, setelah selesai leaflet beramah tamahlah dahulu dengan responden. Ceramah dapat dilakukan oleh semua orang dengan menggunakan power point yang menarik sedangkan Leaflet sangat efektif untuk menyampaikan pesan kesehatan dan kesempatan untuk belajar kembali akan lebih banyak.

Media leaflet berisikan suatu gagasan secara langsung ke pokok permasalahannya dan memaparkan cara melakukan tindakan secara pendek dan lugas. Leaflet sangat efektif untuk menyampaikan pesan singkat dan padat seperti poster, media ini juga mudah dibawa dan disebarluaskan karena ukurannya lebih ringkas dan jumlah yang dibawa lebih banyak dari pada poster. Keuntungan dari leaflet adalah dapat membantu petugas memberikan pelajaran, daya tangkap penglihatan besar, sebagai alat penghubung yang dapat menyampaikan berita-bertita dan penjelasan-penjelasan kepada masyarakat dalam jumlah besar, kesempatan untuk belajar kembali akan lebih banyak, mudah dibawa dan disebar luaskan, proses pembuatan relatif cepat dan murah, efektif untuk pesan yang singkat dan padat, bisa dibuat sederhana.

Berdasarkan analisa penelitian sesudah perlakuan dimana ibu mengikuti pendidikan kesehatan dengan metode ceramah dan leaflet ibu mendapatkan informasi tentang persiapan persalinan dan kelahiran bayi. Perlakuan ini dapat menjadi tambahan informasi pada ibu sehingga pengetahuan ibu bertambah dan termotivasi untuk tidak berfikir negatif terhadap proses persalinan nanti.

Penelitian diatas menunjukan bahwa leaflet sebagai media edukasi memiliki pengaruh terhadap tingkat pengetahuan dan kecemasan ibu hamil. Media ini berisikan suatu gagasan secara langsung ke pokok permasalahannya dan memaparkan cara melakukan tindakan secara pendek dan lugas. Leaflet sangat efektif untuk menyampaikan pesan singkat dan padat, media ini juga mudah dibawa dan disebarluaskan karena ukurannya lebih ringkas.

Tabel 3. Analisa perbedaan Tingkat Kecemasan Ibu Hamil Primigravida Trimester III dalam Menghadapi Persalinan Sebelum dan Sesudah diberikan Pendidikan Kesehatan dengan Metode Ceramah di BPM Y Kota Palembang

\begin{tabular}{cccccc}
\hline Ket & n & Mean & SD & SE & P value \\
\hline Sebelum & 15 & 9,13 & 1,552 & 0,401 & 0,001 \\
Sesudah & & 6,13 & 1,642 & 0,424 & \\
\hline
\end{tabular}

Berdasarkan tabel 3 dapat dijelaskan bahwa rata-rata tingkat kecemasan ibu hamil primigravida trimester III pada kelompok 
sebelum diberikan pendidikan kesehatan dengan metode ceramah adalah 9,13 dan sesudah diberikan pendidikan kesehatan dengan metode ceramah adalah 6,13, sehingga dapat disimpulkan bahwa terjadi penurunan tingkat kecemasan ibu hamil dalam menghadapi persalinan. Hasil menunjukkan ada perbedaan tingkat kecemasan ibu hamil primigravida trimester III sebelum dan sesudah diberikan pendidikan kesehatan dengan menggunakan metode ceramah $(p=0,001)$.

Hasil analisis tersebut menjelaskan bahwa terdapat perbedaan yang bermakna secara statistik nilai rata-rata tingkat kecemasan ibu hamil primigravida trimester III dalam menghadapi persalinan pada kelompok ceramah. Perbedaan tingkat kecemasan ibu hamil pada metode ceramah dikarenakan ibu lebih tertarik dan mendengarkan dari pada ibu harus membaca sendiri. Pendidikan kesehatan menggunakan metode ceramah dapat dilakukan apabila kelompok tersebut telah mendapat informasi sebelumnya karena kelompok itu terlalu besar untuk memakai metode ini, sehingga ceramah hanya ingin menambah atau menekankan apa yang sudah dipelajari.

Tabel 4. Analisa perbedaan Tingkat Kecemasan Ibu Hamil Primigravida Trimester III dalam Menghadapi Persalinan Sebelum dan Sesudah diberikan Pendidikan Kesehatan dengan Metode Leaflet di BPM Y Kota Palembang penurunan rata-rata tingkat kecemasan ibu hamil dalam menghadapi persalinan setelah diberikan pendidikan kesehatan menggunakan leaflet. Hasil menunjukkan ada perbedaan tingkat kecemasan ibu hamil primigravida trimester III sebelum dan sesudah diberikan pendidikan kesehatan dengan menggunakan metode leaflet di BPM Y Kota Palembang $(p=0,000)$.

Hasil analisis tersebut menjelaskan bahwa terdapat perbedaan yang bermakna secara statistik nilai rata-rata tingkat kecemasan ibu hamil primigravida trimester III dalam menghadapi persalinan pada kelompok leaflet. Perbedaan tingkat kecemasan ibu hamil pada metode leaflet dikarenakan apabila ibu lupa dengan apa yang sudah disampaikan maka ibu dapat membuka dan membacanya kembali. Pendidikan kesehatan yang diberikan pada ibu hamil saat melakukan pelayanan antenatal terbukti mampu meningkatkan pengetahuan ibu hamil terhadap kehamilannya. Media cetak terkait edukasi kepada ibu hamil juga telah banyak dimanfaatkan misalnya leaflet. Leaflet sebagai media edukasi telah diteliti memiliki pengaruh terhadap tingkat pengetahuan dan kecemasan ibu hamil.

Tabel 5. Analisa Perbedaan Tingkat Kecemasan Ibu Hamil Primigravida Trimester III dalam Menghadapi Persalinan Sesudah diberikan Pendidikan Kesehatan dengan Metode Ceramah dan Leaflet di BPM Y Palembang

\begin{tabular}{|c|c|c|c|c|c|}
\hline Kelompok & $\mathbf{N}$ & Mean & SD & SE & $\begin{array}{c}\mathbf{P} \\
\text { value }\end{array}$ \\
\hline $\begin{array}{c}\text { Sesudah } \\
\text { ceramah } \\
\text { Sesudah } \\
\text { leaflet }\end{array}$ & 15 & $\begin{array}{l}6,13 \\
9,20\end{array}$ & $\begin{array}{l}1,642 \\
2,426\end{array}$ & $\begin{array}{l}0,424 \\
0,626\end{array}$ & $\overline{0,000}$ \\
\hline
\end{tabular}

Berdasarkan tabel 4 dapat dijelaskan bahwa rata-rata tingkat kecemasan ibu hamil primigravida trimester III pada kelompok sebelum diberikan pendidikan kesehatan dengan metode leaflet adalah 11,80 dan sesudah diberikan pendidikan kesehatan dengan metode leaflet adalah 9,20, terjadi
Berdasarkan tabel 5 dapat dijelaskan bahwa rata-rata tingkat kecemasan ibu hamil primigravida trimester III pada kelompok sesudah diberikan pendidikan kesehatan dengan metode ceramah adalah 6,13 dan sesudah diberikan pendidikan kesehatan dengan metode leaflet adalah 9,20. Hasil 
menunjukan ada perbedaan yang signifikan tingkat kecemasan ibu hamil primigravida trimester III sesudah diberikan pendidikan kesehatan dengan menggunakan metode ceramah dan leaflet pada kelompok sesudah diberi perlakuan berupa leaflet dan sesudah kelompok kontrol yaitu kelompok dengan metode ceramah $(p=0,000)$.

Pengetahuan ibu hamil dalam pelaksanaan kelas ibu hamil setelah diberikan materi tentang perawatan kehamilan menggunakan metode ceramah dengan pemberian leaflet memiliki nilai tertinggi 100, nilai terendah 40, dan median sebesar 85,0 dengan ( $p=0,0001)$. Penyampaian materi yang umumnya dilakukan dengan metode ceramah, kemudian dengan ditunjang oleh metode alternatif pemberian leaflet mampu meningkatkan pengetahuan para ibu hamil, yaitu pengetahuan tentang perawatan kehamilan. (Kundre \& Silolonga, 2014)

Hal ini berarti bahwa rata-rata tingkat kecemasan ibu hamil primigravida trimester III pada kelompok sesudah diberikan pendidikan kesehatan dengan metode leaflet lebih tinggi dari pada kelompok sesudah diberikan pendidikan kesehatan dengan metode ceramah karena metode leaflet sangat efektif untuk menyampaikan pesan singkat dan padat seperti poster, media ini juga mudah dibawa dan disebarluaskan karena ukurannya lebih ringkas dan jumlah yang dibawa lebih banyak dari pada poster.

Materi-materi yang diberikan memiliki informasi penting khususnya tentang persiapan persalinan sehingga harus tersampaikan dengan baik dan tepat pada sasaran yaitu para ibu hamil. Penyampaian materi yang umumnya dilakukan dengan metode ceramah, kemudian dengan ditunjang oleh metode alternatif pemberian leaflet mampu meningkatkan pengetahuan para ibu hamil dalam proses persalinan dan kelahiran bayi

\section{SIMPULAN DAN SARAN}

a. Tingkat kecemasan ibu hamil primigravida trimester III dalam menghadapi persalinan di BPM Y, kota Palembang sebelum diberi leaflet rata-rata 11,80 dari pada kelompok ceramah rata-rata 9,13 .

b. Tingkat kecemasan ibu hamil primigravida trimester III dalam menghadapi persalinan di BPM Y, KotaPalembang sesudah diberi leaflet rata-rata 9,20 dan kelompok ceramah rata-rata 6,13 .

c. Ada perbedaan tingkat kecemasan ibu hamil primigravida trimester III sebelum dan sesudah diberikan pendidikan kesehatan dengan menggunakan metode ceramah nilai $p=0,001$.

d. Ada perbedaan tingkat kecemasan ibu hamil primigravida trimester III sebelum dan sesudah diberikan pendidikan kesehatan dengan menggunakan metode leaflet nilai $p=0,000$.

e. Ada perbedaan tingkat kecemasan ibu hamil primigravida trimester III sesudah diberikan pendidikan kesehatan dengan menggunakan metode ceramah dan leaflet pada kelompok sesudah ceramah dan sesudah kelompok leafle $(p=0,000)$.

\section{SARAN}

Bagi ibu hamil hendaknya melakukan pemeriksaan kehamilan sesuai dengan usia kehamilan minimal 1 kali pada trimester I, 1 kali pada trimester II dan 2 kali pada trimester III, ibu hamil harus mendapat dukungan sosial dan keluarga sehingga membantu mengurangi perasaan cemas karena kehadiran mereka membuat kuat dan lebih percaya diri. Bagi bidan hendaknya memberikan pendidikan kesehatan pada ibu hamil saat memberikan pelayanan pemeriksaan kehamilan menggunakan leaflet atau buka KIA dan menyarankan ibu hamil untuk membaca buku KIA secara tuntas agar ibu menjadi paham 
tentang kondisi kehamilan dan persiapan persalinan sehingga dapat menurunkan tingkat kecemasan ibu hamil dalam menghadapi persalinan.

\section{DAFTAR PUSTAKA}

Arief. (2010). Kehamilan Dan Kelahiran Sehat. Yogyakarta : Dianloka.

Dagu, S. M. (2010). Psikologi Keluarga: Peran Ayah Dalam Keluarga. Jakarta: Rineka Cipta.

Ilmiasih, R. (2014). Pengaruh Tehnik Hypnobirthing Terhadap Tingkat Kecemasan Ibu Hamil Pada Masa Persiapan Menghadapi Persalinan.

Induniasih, W. R. (2018). Promosi Kesehatan Pendidikan Kesehatan Dalam Keperawatan (1st Ed.). Induniasih, W. Ratna.

Kundre, N. N. W. R., \& Silolonga, W. (2014). Hubungan Pengetahuan Ibu Hamil Primigravida Trimester Iii Dengan Tingkat Kecemasan Ibu Menghadapi Persalinandi Poli Kia, 1-8.

Pevi Primasnia, Wagiyo, E. (2013). Hubungan Pendampingan Suami Dengan Tingkat Kecemasan Ibu Primigravida Dalam Menghadapi Proses Persalinan Kala I Di Rumah Bersalin Kota Ungaran, 212-216.

Pramudianti, D. N. (2017). Pengaruh Edukasi Postpartum Dengan Media Booklet Pada Ibu Pasca Sectio Caesarea Terhadap Parenting Self-Efficacy Pada Periode Awal Masa Nifas Di Rumah Sakit Wilayah Klaten.

Rahmat, I., \& Siswosudarmo, R. (2014). Pengaruh Pendidikan Kesehatan Terhadap Kecemasan Primigravida
Dalam Menghadapi Persalinan, 1(3), 166-174.

Risqi, H. (2015). Upaya Mengurangi Kecemasan Primigravida Trimester Iii Dalam Menghadapi Persalinan. 